Article

\title{
Evaluation of Different Urban Microclimate Mitigation Strategies through a PMV Analysis
}

\section{Ferdinando Salata ${ }^{1, *}$, Iacopo Golasi ${ }^{1}$, Emanuele de Lieto Vollaro ${ }^{2}$, Fabio Bisegna ${ }^{1}$, Fabio Nardecchia ${ }^{1}$, Massimo Coppi ${ }^{1}$, Franco Gugliermetti ${ }^{1}$ and Andrea de Lieto Vollaro ${ }^{1}$}

1 DIAEE-Area Fisica Tecnica, Università degli Studi di Roma "Sapienza", Via Eudossiana, 18-00184 Rome, Italy; E-Mails: iacopo.golasi@uniroma1.it (I.G.); fabio.bisegna@uniroma1.it (F.B.); fabio.nardecchia@uniroma1.it (F.N.); massimo.coppi@uniroma1.it (M.C.); franco.gugliermetti@uniroma1.it (F.G.); andrea.delietovollaro@uniroma1.it (A.L.V.)

2 DIMI-Università degli Studi “Roma TRE”, Via Vito Volterra, 62-00146 Rome, Italy; E-Mail: emanuele.delietovollaro@uniroma3.it

* Author to whom correspondence should be addressed; E-Mail: ferdinando.salata@uniroma1.it; Tel.: +39-06-44585661; Fax: +39-06-4880120.

Academic Editor: Marc A. Rosen

Received: 28 May 2015 / Accepted: 7 July 2015 / Published: 10 July 2015

\begin{abstract}
Outdoor thermal comfort affects the health of the people and the quality of life in urban areas. This is the reason why in the past few years different mitigation strategies for the microclimate have been studied and examined. These strategies depend on those passive factors characterizing the urban setting that are able to affect the values of local meteorological variables, as the limit surfaces of the urban space (parterre and façades of the buildings). This paper examines the Cloister by Giuliano da Sangallo, which is part of the Faculty of Engineering of Sapienza University of Rome. The case study compares the present configuration of the Cloister with four other configurations characterized by some vegetation and materials with a high albedo by taking into consideration the PMV (Predicted Mean Vote) model. Microclimatic variables are calculated through numerical simulations performed by the ENVI-met software. Such a comparison is performed during a typical summer day. While examining the results it can be noticed how the strategy presenting the best results is the one with some vegetation, whereas the materials with a high albedo improve the microclimate if applied on surfaces characterized by a high sky view factor.
\end{abstract}


Keywords: outdoor thermal comfort; PMV; mitigation strategies; urban microclimate; ENVI-met

\section{Introduction}

During the past few years, the urbanization process caused atmospheric changes, which led to higher temperatures in cities than those characterizing the surrounding non-urban areas.

The examination of such phenomenon started in the XIX century [1] and lately it has caught the attention of the international scientific community, as showed by some studies carried out in different countries: Lodz (Poland) [2], Athens (Greece) [3], Beijing (China) [4], Aveiro (Portugal) [5].

This phenomenon, together with an increase in temperature in the cities, is the result of urban/rural energy budget differences [6]. For what concerns the radiation balance, the differences between urban and rural areas are not that significant [6,7] and the larger nighttime radiative loss determined by the high emissivity [8] compensates for the higher amount of energy input in the daytime in urban areas determined by a low albedo [8]. The increase in temperature in urban areas is so connected to the type of materials used. For example, the vegetation tends to cover just a small part of the surface in cities, thus the evapotranspiration is highly reduced and urban areas convert their radiant energy into sensible heat rather than latent heat [6]. The change of urban energy budget determined by a low albedo and the reduced evapotranspiration cause a higher urban energy input in the daytime [8]. Such excess of energy is usually stored: the thermal properties (e.g., heat capacity, thermal conductivity) of the materials used in the cities and the complex and traditional urban morphology increase the heat flux stored in these areas [9-13]. The surfaces start releasing the stored energy during the night [8], slowing down the cooling process in the cities and determining a temperature difference between urban and rural areas.

Sky view factor values are also able to facilitate the sensible heat stored at lower layers: in fact, during the night a low sky view factor reduces the disposal of the longwave radiation in urban areas determining temperature differences between urban and rural areas that can be 3.3 times higher than those measured during the daytime [14] where the energy budget is regulated by the incident solar radiation [15].

The excess warmth of the urban atmosphere is then observed especially in the Urban Canopy Layer (UCL), extending from the surface to the mean buildings height [6]. This phenomenon affects the human thermal comfort [16,17], which has been widely examined in indoor spaces as offices, schools and houses [18-23]. However, many recreational activities of considerable commercial value are conducted outdoors (e.g., sporting events, theme parks, cultural events, etc...) and an increasing number of weather sensitive businesses in the service sector, such as restaurants and cafes, are taking advantage of outdoor environments [24]. It should be also considered that outdoor thermal comfort is one of the main factors affecting the habitability of a space and the quantity and frequency of activities depend on the quality of the microclimatic conditions [25]. This is why urban areas must be planned by implementing, where necessary, proper mitigation strategies. Some of these strategies, partially affecting each other, are: the use of high albedo surfaces [26-30], evaporation from porous surfaces [31,32], evaporation from 
ground-level water surfaces [33] and roof ponds [34], vegetated surfaces [35], rooftop gardens [36-40], and trees $[27,41]$.

This paper, through the examination of a case study concerning the Cloister of San Pietro in Vincoli (placed right inside the Faculty of Engineering of the Sapienza University of Rome), evaluates how some of the mitigation strategies previously mentioned affect the microclimate and the outdoor thermal comfort. Particular attention is given to the influence determined by the presence of high albedo materials (characterized by higher values of the reflectance in the region of infrared and lower values in the region of visible) and some vegetation: this is the reason why different configurations of the site were compared. The selected performance metric is then the comfort sensation of a pedestrian standing in the Cloister, whereas the outdoor thermal comfort is estimated through the PMV (Predicted Mean Vote). This index, developed by Fanger [42], it is based on 1565 thermal comfort questionnaires distributed for the evaluation of the thermoigrometric qualities of indoor spaces and it was then adapted to outdoor spaces taking into account the presence of solar radiation [43]. It takes into consideration the following environment variables: air temperature, mean radiant temperature, relative humidity, wind speed and some operative variables as clothing insulation and the metabolic rate.

\section{Case Study}

The case study of this paper focuses on the Cloister of San Pietro in Vincoli (Figure 1), placed next to the basilica with the same name and right inside the Faculty of Engineering of the "Sapienza" University of Rome.
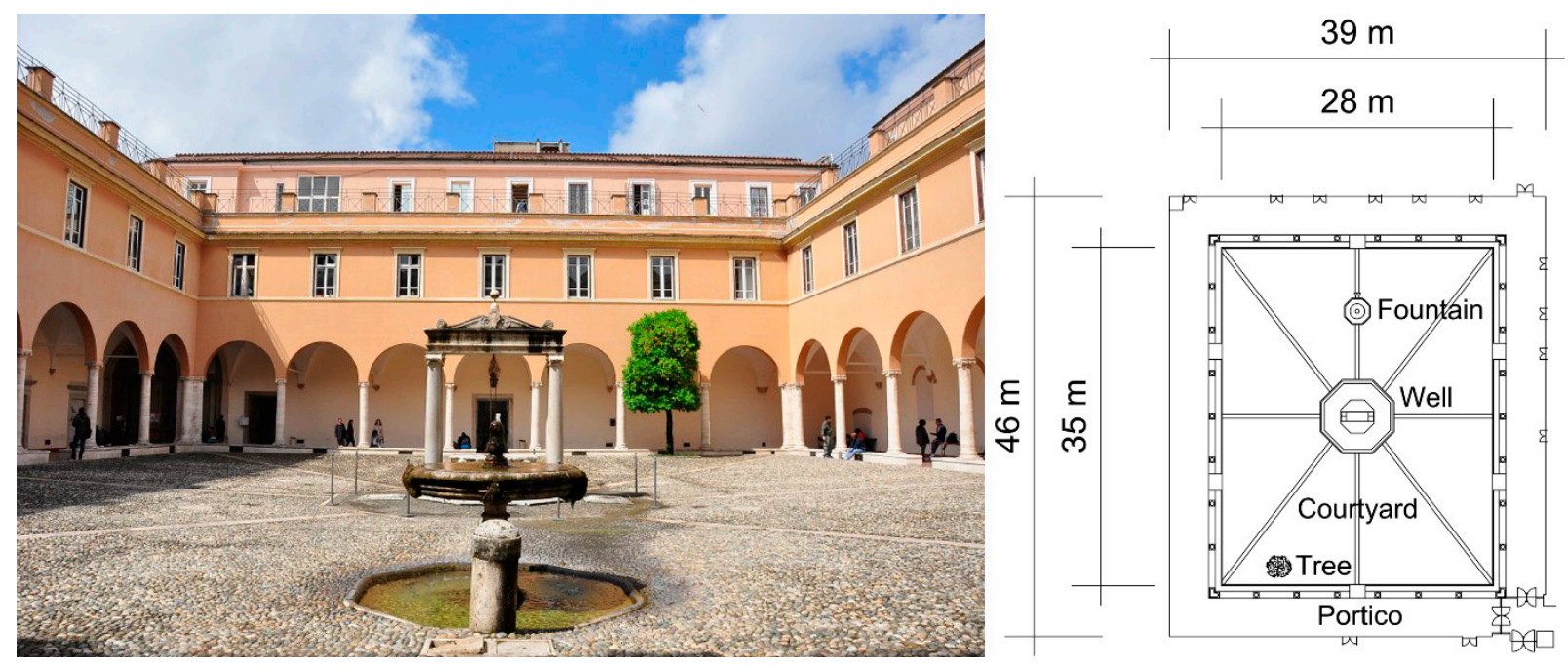

Figure 1. Dimensions and present configuration of the Cloister of the Faculty of Engineering of the "Sapienza" University.

It is a Renaissance structure by Giuliano da Sangallo. The ground-floor has a rectangular portico whose sides present seven or eight arches supported by columns, while the centre of the yard is characterized by an octagonal well by Simone Mosca. On top of it there is a trestle formed by two pairs of columns supporting an architrave, which it is thought to be a work by Michelangelo Buonarroti. The yard, made of Lombard cobblestones, also presents a well and an orange tree while the portico paving is made of ceramic tiles. 
For what concerns the city of Rome, it is characterized by a latitude of $41^{\circ} 55^{\prime} \mathrm{N}$, a longitude of $12^{\circ} 29^{\prime} \mathrm{E}$ and a height of $20 \mathrm{~m}$ above the sea level [44]. It is the most populated and the widest city of Italy respectively with $2,844,821$ inhabitants and $1285.30 \mathrm{~km}^{2}$.

It is characterized by the typical Mediterranean climate, mild and comforting in the spring and fall. Spring and autumn are then the rainiest seasons, especially in November and April. The summer is hot, humid and usually with infrequent precipitation, whereas the winter is rainy and rarely cold. Table 1 shows the average values for each season of the most important meteorological variables [45-47].

Table 1. Average values for all seasons of the air temperature, relative humidity, wind speed and direction in Rome.

\begin{tabular}{ccccc}
\hline & $\begin{array}{c}\text { Summer } \\
\text { (Jun-Aug) }\end{array}$ & $\begin{array}{c}\text { Fall } \\
\text { (Sep-Nov) }\end{array}$ & $\begin{array}{c}\text { Winter } \\
\text { (Dec-Feb) }\end{array}$ & $\begin{array}{c}\text { Spring } \\
\text { (Mar-May) }\end{array}$ \\
\hline Air temperature [ $\left.{ }^{\circ} \mathrm{C}\right]$ & 23.3 & 17.1 & 8.9 & 13.8 \\
Relative humidity [\%] & 76.0 & 77.3 & 79.3 & 78.0 \\
Wind speed [m/s] & 3.3 & 4.1 & 3.7 & 3.8 \\
Wind direction [N = 0 or 360, & 146.1 & 134.5 & 125.2 & 157.4 \\
E =90, S = 180, W = 270] & & & & \\
\hline
\end{tabular}

According to Köppen classification, this climate belongs to the Csa category [48] (Figure 2).

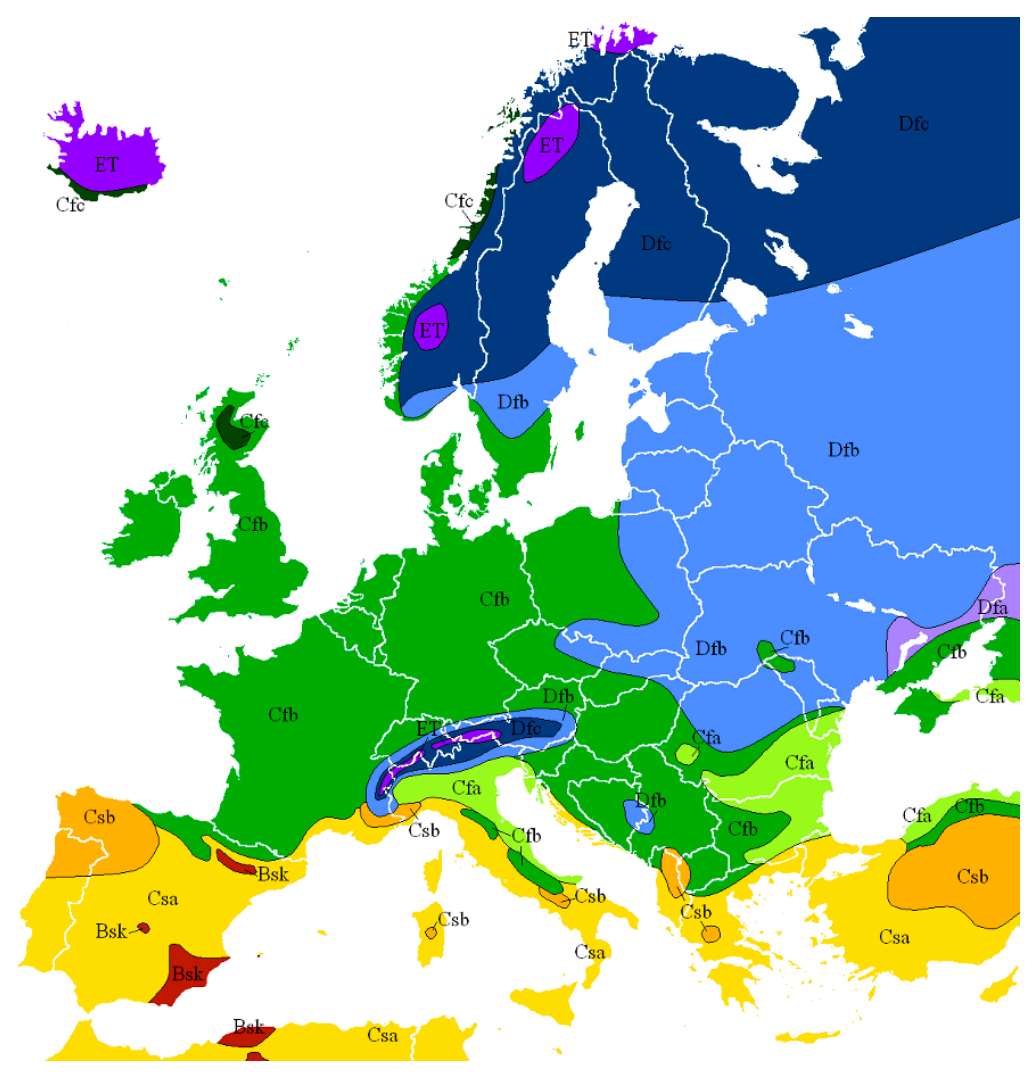

Figure 2. Köppen climate classification.

Table 2 shows the criteria defining, according to this classification, mild climates and therefore the Mediterranean climate as well. 
Table 2. Description of the symbols of Köppen climate classification and defining criteria (for $\mathrm{C}$ category, representing mild climates).

\begin{tabular}{ccccc}
\hline 1st & 2nd & 3rd & Description & Criteria \\
\hline $\mathrm{C}$ & & & Mild & $\mathrm{T}_{\mathrm{HOT}}>10$ and $0<\mathrm{T}_{\mathrm{COLD}}<18$ \\
& $\mathrm{~s}$ & & Dry summer & $\mathrm{P}_{\mathrm{SDRY}}<40$ and $\mathrm{P}_{\mathrm{SDRY}}<\mathrm{P}_{\mathrm{WWET}} / 3$ \\
& $\mathrm{~W}$ & & Dry winter & $\mathrm{P}_{\mathrm{WDRY}}<\mathrm{P}_{\mathrm{SWET}} / 10$ \\
& $\mathrm{f}$ & & Without dry season & Not $(\mathrm{Cs})$ or $(\mathrm{Cw})$ \\
& & $\mathrm{a}$ & Hot summer & $\mathrm{T}_{\mathrm{HOT}} \geq 22$ \\
& $\mathrm{~b}$ & Warm summer & Not $(\mathrm{a})$ and $\mathrm{T}_{\mathrm{MON} 10} \geq 4$ \\
& & $\mathrm{c}$ & Cold summer & Not (a or b) and $1 \leq \mathrm{T}_{\mathrm{MON} 10}<4$ \\
\hline
\end{tabular}

\section{Other Configurations of the Site}

In order to make an evaluation of how the urban context affects the thermal comfort in the Mediterranean area, the present configuration of the Cloister is compared to other four configurations.

The present configuration (conf. 1) is the one that has been characterizing the Cloister since the latest building restructuring: the basic surface of the yard is made of cobblestones, while the portico of ceramic tiles. For what concerns the vertical limits of the structure, they present painted lime plaster.

In order to evaluate how vegetation and a higher albedo coefficient affect human thermal sensations, four different configurations by changing the materials of the facades and of the basic surface of the yard have been designed. The surfaces are reported in Figure 3.

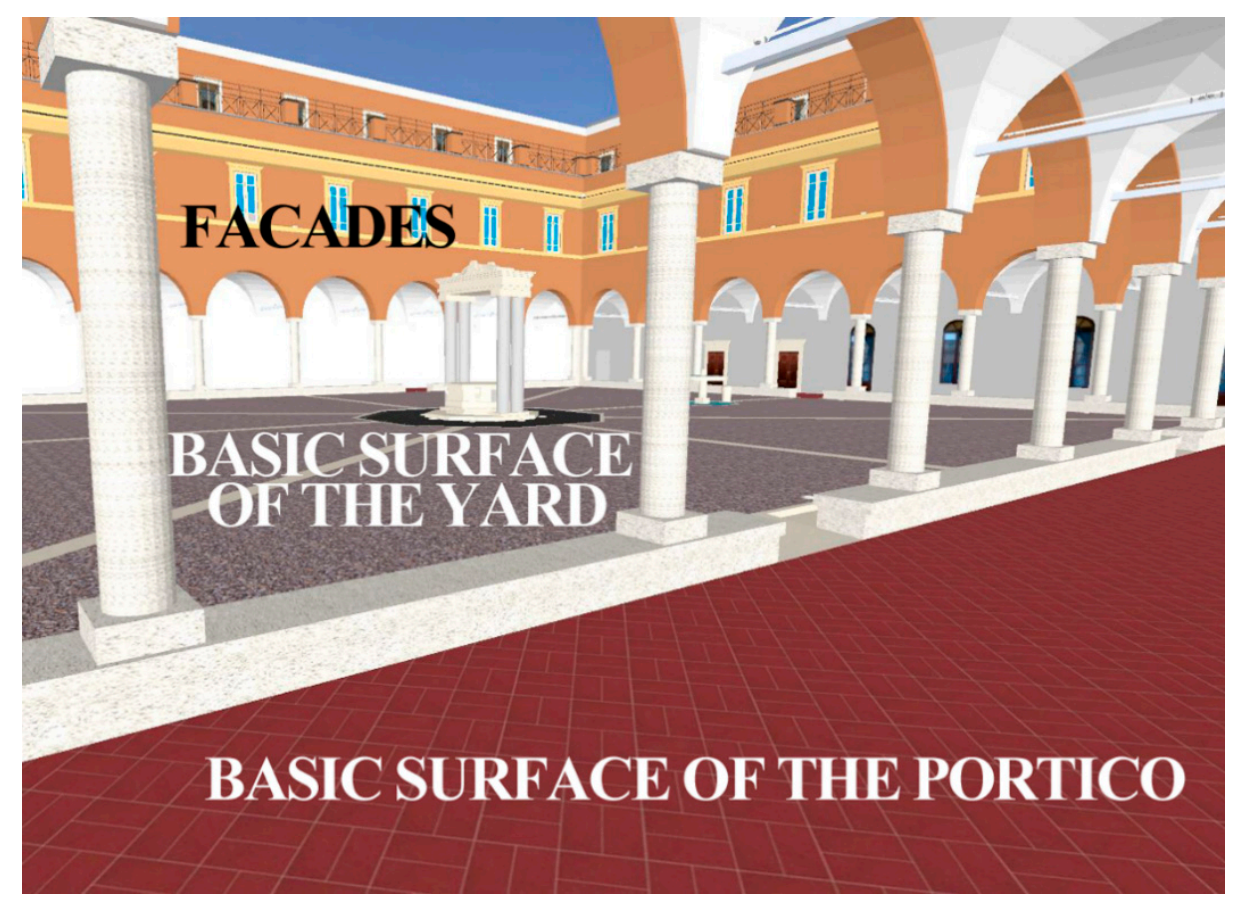

Figure 3. 3D-model of the Cloister and identification of the various surfaces.

This is why a first alternative configuration (conf. 2) is characterized by the facades surrounding the Cloister without any changes, whereas it is assumed the presence of a lawn and some vegetation, such as plants and shrubs, in the yard. This was the configuration of the cloister before the last restoration (Figure 4). 


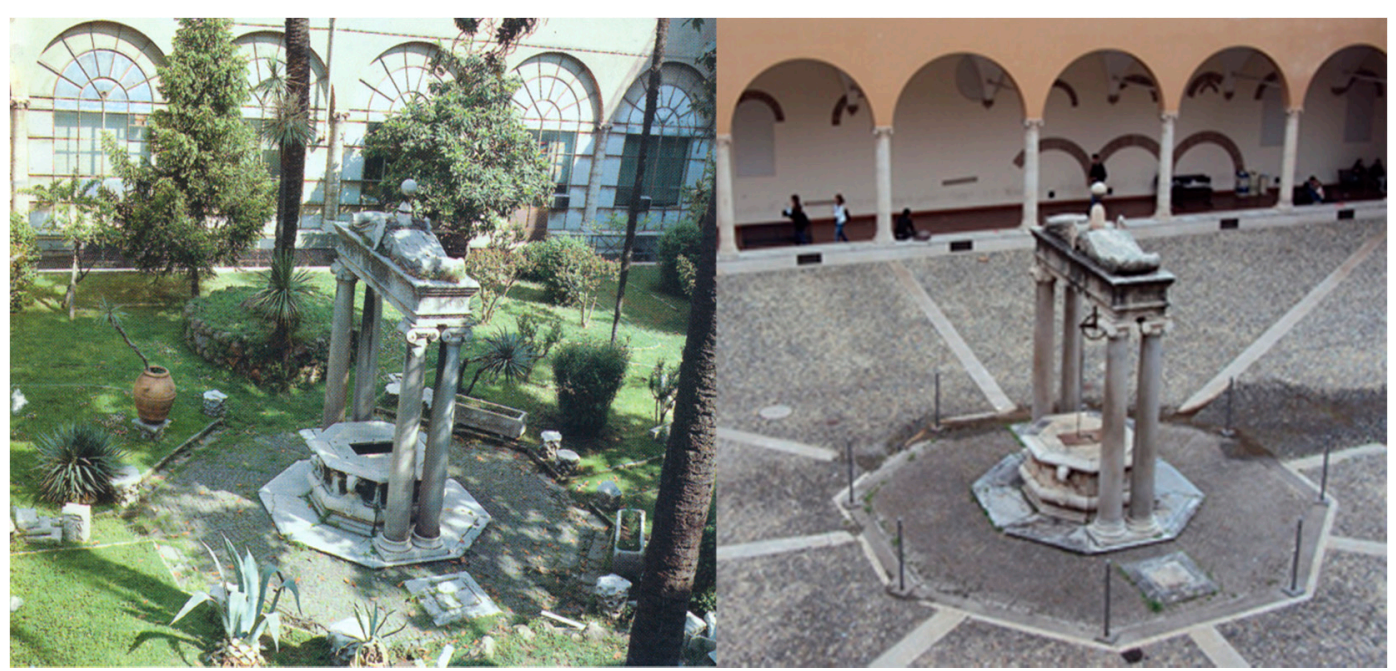

Figure 4. Cloister: on the left conf. 2 with the garden (picture taken in the 90s), on the right conf. 1 with cobblestones (present days).

In the second alternative configuration (conf. 3), the albedo coefficient of the yard increases while the facades remain unchanged (as in conf. 1 and in conf. 2).

In the third alternative configuration (conf. 4), the structural solution presents a higher albedo coefficient characterizing the facades and the yard surface.

Finally, the fourth alternative configuration (conf. 5) combines both mitigation strategies: it is characterized by a lawn and some vegetation in the yard and, at the same time, the albedo coefficient of the facades increases.

Table 3 reports the planning choices of each configuration.

Table 3. Planning choices of the five configurations examined.

\begin{tabular}{|c|c|c|c|c|c|c|}
\hline & & \multirow{2}{*}{$\begin{array}{c}\text { Present Conf. } \\
\text { Conf. } 1 \\
\end{array}$} & \multicolumn{4}{|c|}{ Alternative Confs. } \\
\hline & & & Conf. 2 & Conf. 3 & Conf. 4 & Conf. 5 \\
\hline \multirow[b]{2}{*}{ Facades } & Painted lime plaster & $\mathrm{X}$ & $\mathrm{X}$ & $\mathrm{X}$ & & \\
\hline & $\begin{array}{c}\text { High albedo } \\
\text { material }\end{array}$ & & & & $\mathrm{X}$ & $\mathrm{X}$ \\
\hline \multirow{3}{*}{ Basic surface of the yard } & Cobblestone & $\mathrm{X}$ & & & & \\
\hline & $\begin{array}{c}\text { High albedo } \\
\text { material }\end{array}$ & & & $\mathrm{X}$ & $\mathrm{X}$ & \\
\hline & $\begin{array}{l}\text { Lawn and } \\
\text { vegetation }\end{array}$ & & $\mathrm{X}$ & & & $\mathrm{X}$ \\
\hline Basic surface of the portico & Ceramic tiles & $\mathrm{X}$ & $\mathrm{X}$ & $\mathrm{X}$ & $\mathrm{X}$ & $\mathrm{X}$ \\
\hline
\end{tabular}

Configurations 2 and 5 also present, besides the lawn, 12 orange trees, two palms and six shrubs. In order to recognize the characteristics of each plant, Table 4 reports: the height $\mathrm{ZP}$, albedo coefficient $\alpha_{\mathrm{F}}$ and the "Leaf Area Density" (LAD) [49]. This is why each plant was assumed to be divided into 10 blocks, each with a height of $1 / 10$ of the total height and for every block the "Leaf Area Density" was calculated through the following relationship [49]: 


$$
L A D(z)=L A D_{m}\left(\frac{z_{p}-z_{m}}{z_{p}-z}\right)^{n} \exp \left[n\left(1-\frac{z_{p}-z_{m}}{z_{p}-z}\right)\right]
$$

Table 4. Leaf Area Density values, height and albedo coefficient of the plants characterizing configurations 2 and 5.

\begin{tabular}{|c|c|c|c|c|}
\hline & Orange Tree & Palm Tree & Shrub & Grass \\
\hline LAD $1\left[\mathrm{z} / \mathrm{z}_{\mathrm{p}}=0.1\right]$ & 0.000 & 0.000 & 0.100 & 0.300 \\
\hline LAD $2\left[\mathrm{z} / \mathrm{z}_{\mathrm{p}}=0.2\right]$ & 0.000 & 0.000 & 0.150 & 0.300 \\
\hline LAD $3\left[\mathrm{z} / \mathrm{z}_{\mathrm{p}}=0.3\right]$ & 0.000 & 0.000 & 0.300 & 0.300 \\
\hline $\mathrm{LAD} 4\left[\mathrm{z} / \mathrm{z}_{\mathrm{p}}=0.4\right]$ & 0.070 & 0.000 & 0.400 & 0.300 \\
\hline LAD $5\left[\mathrm{z} / \mathrm{z}_{\mathrm{p}}=0.5\right]$ & 0.275 & 0.000 & 0.650 & 0.300 \\
\hline LAD $6\left[\mathrm{z} / \mathrm{z}_{\mathrm{p}}=0.6\right]$ & 0.500 & 0.000 & 0.700 & 0.300 \\
\hline LAD $7\left[\mathrm{z} / \mathrm{z}_{\mathrm{p}}=0.7\right]$ & 1.060 & 0.120 & 0.850 & 0.300 \\
\hline $\mathrm{LAD} 8\left[\mathrm{z} / \mathrm{z}_{\mathrm{p}}=0.8\right]$ & 1.000 & 1.100 & 0.750 & 0.300 \\
\hline LAD $9\left[\mathrm{z} / \mathrm{z}_{\mathrm{p}}=0.9\right]$ & 0.850 & 1.300 & 0.550 & 0.300 \\
\hline LAD $10\left[\mathrm{z} / \mathrm{z}_{\mathrm{p}}=1.0\right]$ & 0.000 & 0.000 & 0.000 & 0.000 \\
\hline $\mathrm{z}_{\mathrm{p}}$ & 8.000 & 15.000 & 1.000 & 0.050 \\
\hline$\alpha_{\mathrm{F}}$ & 0.200 & 0.200 & 0.200 & 0.200 \\
\hline
\end{tabular}

Then, Table 5 reports some thermophysical properties of the materials characterizing the limits surfaces of the structure in every configuration:

Table 5. Thermophysical properties of the materials used for the limits surfaces of the Cloister.

\begin{tabular}{ccccc}
\hline & Painted Lime Plaster & High Albedo Material & Cobblestone & Ceramic Tiles \\
\hline$\varepsilon_{\mathrm{S}}$ & 0.900 & 0.890 & 0.900 & 0.880 \\
$\alpha_{\mathrm{S}}$ & 0.270 & 0.660 & 0.400 & 0.370 \\
\hline
\end{tabular}

In detail, the high albedo material coefficients were chosen according to previous research [50] related to the development of innovative materials with the same spectral response of those used in historical centers in the visible region, but high reflectance in another solar spectrum range. In this way, it is possible to respect the architectural restrictions of the historical buildings.

\section{The Software: ENVI-met}

In order to evaluate how the different mitigation strategies affect the microclimate and outdoor thermal comfort, ENVI-met was the prediction software used [51,52]. It is a 3D prognostic microclimate model designed to simulate the interactions among buildings, surfaces, vegetation and air in an urban context. It relies on the fundamental laws of fluid dynamics and thermodynamics and it can be used with a typical resolution of $0.5-10 \mathrm{~m}$ in space and $1-10 \mathrm{~s}$ in time. The model can simulate:

- $\quad$ flow around and between buildings;

- exchange processes of heat and vapor at urban surfaces;

- turbulence;

- $\quad$ exchanges of energy and mass between vegetation and its surroundings. 
The main input parameters of an ENVI-met simulation include: weather conditions, initial soil wetness and temperature profiles, structures and physical properties of urban surfaces, and plants. Several scientific studies certify its reliability $[53,54]$. The software is able to calculate the values of several meteorological and microclimatic variables (e.g., wind speed and direction, potential temperature, specific humidity, relative humidity, mean radiant temperature, direct, diffuse and reflected shortwave radiation, longwave radiation) and the PMV (Predicted Mean Vote); it also takes into consideration how evapotranspiration phenomena, determined by the presence of vegetation and permeable soils, affect this index thus ensuring a comparison, as in this paper, of different mitigation strategies.

\section{The PMV}

As previously mentioned, different mitigation strategies are compared thanks to the PMV (Predicted Mean Vote) [42]. This is a thermal comfort index which at first was developed for indoor environments based on some tests (1,565 people were surveyed). Afterwards, it was modified and adapted to examine outdoor environments as well [43].

The PMV predicts the mean value of the votes of a large group of persons and it is defined as follows [55]:

$$
P M V=\left(0.303 \cdot e^{-0.036 M}+0.028\right) \cdot S
$$

where $\mathrm{M}$ is the metabolic rate and $\mathrm{S}$ is the storage deriving from the energy budget equation describing the heat exchange between the human body and the thermal environment. The equation is defined as follows:

$$
M+W+Q\left(T_{M R}, v\right)+Q_{H}\left(T_{A}, v\right)+Q_{L}(e, v)+Q_{S W}(e, v)+Q_{R E}\left(T_{A}, e\right)=S
$$

where $\mathrm{W}$ is the physical work output; $\mathrm{Q}$ is the radiation budget, a function of mean radiant temperature $\mathrm{T}_{\mathrm{MR}}$ and air velocity $\mathrm{v} ; \mathrm{Q}_{\mathrm{H}}$ is the turbulent heat flux of sensible heat, a function of air temperature $\mathrm{T}_{\mathrm{A}}$ and air velocity v; QL is the latent heat flow due to evaporation of moisture diffused through the skin, a function of air humidity e and velocity v; QSw is the latent heat flow from sweat evaporation; QRE is the respiratory heat flux (sensible and latent). Each term of Equation (3) is expressed in $\left[\mathrm{W} / \mathrm{m}^{2}\right]$ and it is positive if it is representative of energy benefit to the body: this is why $M$ is always positive while W, QL and Qsw are always negative.

For what concerns the PMV scale it ranges between -4 (very cold) and +4 (very hot) where 0 is the thermal neutral (comfort) value. It should not be forgotten that the PMV is a function of the local climate and its values can exceed the interval $(-4) \div(+4)$. The PMV is then a stationary value and this means that a person is supposed to be exposed for a long time to a certain climatic situation until the energy exchange processes with the human body will be stationary.

The use of this rational index is suggested by the German engineering guidelines VDI 3787 [56], which were developed for outdoor environments, and by ISO 7730 [57] and ASHRAE 55 [58], which were designed for indoor environments. For these reasons, the PMV is one of the most widely used indexes to evaluate outdoor thermal comfort [59]. Becker et al. [60] evaluated the correlation of observed and calculated thermal sensation values according to this index for four different locations in the area of Kibbutz Yotvata (Israel) and they found that the correlation coefficient ranged between 0.60 and 0.81 with an average of 0.70 . Similar results were obtained by Bouden and Ghrab [61]: they 
carried out a cross-sectional investigation in five different Tunisian cities finding a correlation coefficient of about 0.71. Differently, the results of a study conducted by Cheng et al. [62] in Hong Kong show that PMV generally overestimates the thermal sensation towards the warmer end of the scale in summer and vice versa in winter. Thorsson et al. [63] reached similar conclusions in the city of Göteborg (Sweden): they compared thermal sensations assessed by the PMV and thermal sensations obtained through interviews finding that the PMV curve was skewed towards the warm zone. Another study was carried by Mahmoud [64] in Egypt and it examined nine zones representing various spaces inside an urban park located in Cairo: even if this study used the PET (Physiological Equivalent Temperature) [65], the authors highlighted how, for one of these zones, the calculated PMV was not significantly different from the mean thermal sensation vote obtained from subjective questionnaires. Finally, Oertel et al. [66] carried out a study in Glasgow (UK) and they found a satisfactory similarity between the PMV and the actual thermal sensation votes derived from outdoor surveys.

\section{Simulations}

The ENVI-met software performed some simulations to compare different mitigation strategies. This is the reason why it was developed a 3D model of the Cloister of San Pietro in Vincoli together with a mesh of $(27 \times 30)$ horizontal cells and 29 vertical cells; the horizontal spacing is of $2 \mathrm{~m}$, while the vertical one is of $0.5 \mathrm{~m}$ where $0 \mathrm{~m} \leq \mathrm{z} \leq 3 \mathrm{~m}$; differently for higher heights, the vertical spacing is calculated through the following relationship:

$$
h_{C(\mathrm{j})}=h_{C(\mathrm{j}-1)}+s \cdot h_{C(\mathrm{j}-1)}
$$

where s represents the extension factor equal to $20 \%$.

For what concerns the simulations, as demonstrated in other works, the choice of the input parameters is very important. For this reason, every simulation was performed with a $2 \mathrm{~s}$ time step. The simulations presented then a variation in the structural solution of the vertical and horizontal limits of the site examined (Tables 3-5), whereas the environmental and meteorological input parameters and the settings for the PMV estimation were the same (Table 6).

Table 6. Input parameters for the ENVI-met simulations.

\begin{tabular}{|c|c|}
\hline \multicolumn{2}{|l|}{ Main Data } \\
\hline Wind speed in $10 \mathrm{~m}$ above ground $[\mathrm{m} / \mathrm{s}]$ & 9.16 \\
\hline Wind direction $[\mathrm{N}=0$ or $360, \mathrm{E}=90, \mathrm{~S}=180, \mathrm{~W}=270]$ & 146.1 \\
\hline Roughness length $Z_{0}$ at reference point $[\mathrm{m}]$ & 1 \\
\hline Initial temperature atmosphere $[\mathrm{K}]$ & 302 \\
\hline Specific humidity in $2500 \mathrm{~m}$ [g water/kg air] & 7 \\
\hline Relative humidity in $2 \mathrm{~m}$ [\%] & 35 \\
\hline \multicolumn{2}{|l|}{ Building Properties } \\
\hline Inside temperature $[\mathrm{K}]$ & 299 \\
\hline Heat transmission walls $\left[\mathrm{W} / \mathrm{m}^{2} \mathrm{~K}\right]$ & 1.25 \\
\hline Heat transmission roofs $\left[\mathrm{W} / \mathrm{m}^{2} \mathrm{~K}\right]$ & 1.54 \\
\hline Albedo walls [ad] & $0.27 / 0.66 *$ \\
\hline Albedo roofs $[\mathrm{ad}]$ & 0.22 \\
\hline
\end{tabular}


Table 6. Cont.

\begin{tabular}{lc}
\hline \multicolumn{2}{c}{ Settings for Soil } \\
\hline Initial temperature upper layer $(0-20 \mathrm{~cm})[\mathrm{K}]$ & 292 \\
Initial temperature middle layer $(20-50 \mathrm{~cm})[\mathrm{K}]$ & 291 \\
Initial temperature deep layer (below $50 \mathrm{~cm})[\mathrm{K}]$ & 289 \\
Relative humidity upper layer $(0-20 \mathrm{~cm})[\%]$ & 50 \\
Relative humidity middle layer $(20-50 \mathrm{~cm})[\%]$ & 60 \\
Relative humidity deep layer (below $50 \mathrm{~cm})[\%]$ & 60 \\
\hline \multicolumn{2}{c}{ Clouds } \\
\hline Fraction of low clouds [x/8] \\
Fraction of medium clouds [x/8] \\
Fraction of high clouds [x/8] \\
\hline \multicolumn{2}{c}{ Settings for PMV-Calculation } \\
\hline Walking speed [m/s] & 0 \\
Metabolic rate [W/m²] & 0.0 \\
Mechanical factor & 70 \\
Thermal resistance of clothing [clo] & 0.0 \\
\hline depends on the choices made for each configuration (Tables 3 and 5).
\end{tabular}

Table 6 reports the main data inserted into the software to reproduce a typical summer day. The wind speed, in $10 \mathrm{~m}$ above the ground level, was estimated through Equation (5) [67]:

$$
R=\frac{v}{v_{10}}
$$

In this case study, where an urban area is examined and giving $\mathrm{v}$ as the value reported in Table $1, \mathrm{R}$ is 0.36 [67] and therefore $\mathrm{v}_{10}$ is 9.16 .

For what concerns the wind direction the value was of 146.1, representing the direction where it presents the highest frequency during the summer (Table 1); on the other hand the choice of the roughness length $Z_{0}$ depends on the position of the site examined in the urban area.

Then, it is important to specify that the initial temperature of the atmosphere is expressed in potential temperature, referable to the absolute temperature through Equation (6):

$$
\theta=T_{A} \cdot\left(\frac{1000}{p_{1}}\right)^{K}
$$

where:

- $\theta$ is the potential temperature $[\mathrm{K}]$;

- $\quad \mathrm{T}_{\mathrm{A}}$ is the air temperature $[\mathrm{K}]$;

- $\mathrm{P}_{1}$ is the pressure whose value is used to calculate $\mathrm{T}_{\mathrm{A}}[\mathrm{hPa}]$;

$-\mathrm{K}=0.286$.

Deciding which building properties to select depends on the direct observation of the site [68-72], while the inside temperature of indoor spaces is set to $299 \mathrm{~K}$ [73].

Instead, the settings for the soil were inserted based on those values that can be measured in a typical Mediterranean area during the summer [74] while the cloud cover was set to 0/8 for low, 
medium and high altitude to reproduce a day characterized by a cloudless sky and high values of direct shortwave radiation.

On the other hand, to make an estimation of the PMV, it was taken into consideration the thermal sensation of a person standing in the site (with a metabolic rate $M$ of $70 \mathrm{~W} / \mathrm{m}^{2}$ and with a mechanical factor $\eta$ of 0.0 ), whereas the clothing thermal resistance was assumed to be of 0.35 clo $\left(1 \mathrm{clo}=0.155 \mathrm{~m}^{2} \mathrm{~K} / \mathrm{W}\right)$. Such value represents the thermal resistance of a typical summer clothing and this choice, as the one concerning the activity performed by the person (serving as a sample), depends on a direct observation of the people attending the site examined.

\section{Results and Discussions}

The results provided by the simulations gave the possibility to compare, in terms of the PMV, the effectiveness of the different mitigation strategies (Figure 5). This is why the PMV is evaluated at the height of $1.1 \mathrm{~m}$ on the ground level, representing the height of the human body centre of gravity of people standing [75]. Afterwards, the case study focused on a typical summer day because the Mediterranean climate presents higher thermal stresses affecting people during the summer (the hottest summer month reports an average temperature higher than $\left.22^{\circ} \mathrm{C}[48]\right)$.

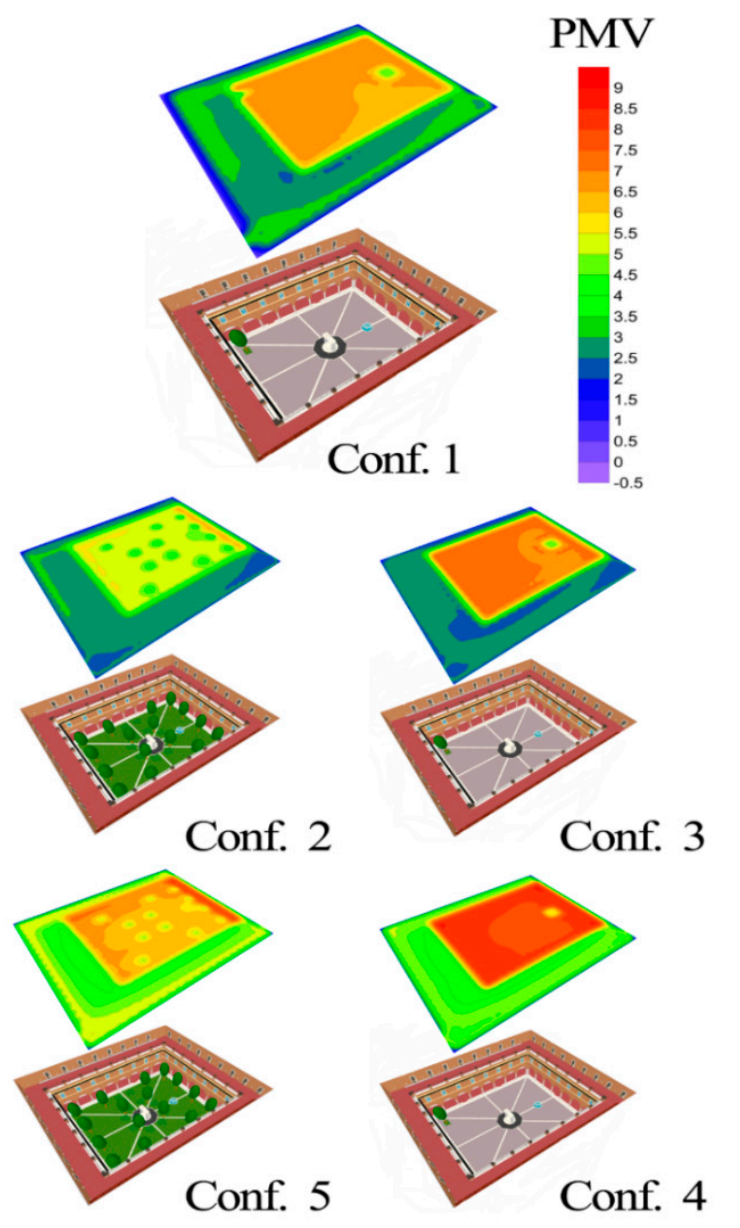

Figure 5. PMV maps of the different configurations.

Table 7 reports, considering each configuration and PMV ranges of a single unit, the corresponding $\mathrm{m}^{2}$ of the Cloister surface and the mean PMV. 
Table 7. PMV analysis of each configuration.

\begin{tabular}{cccccc}
\hline PMV range & Conf. $\mathbf{1}\left[\mathbf{m}^{\mathbf{2}}\right]$ & Conf. 2 $\left[\mathbf{m}^{\mathbf{2}}\right]$ & Conf. $\mathbf{3}\left[\mathbf{m}^{\mathbf{2}}\right]$ & Conf. $\mathbf{4}\left[\mathbf{m}^{\mathbf{2}}\right]$ & Conf. $\mathbf{5}\left[\mathbf{m}^{\mathbf{2}}\right]$ \\
\hline $0-1$ & 19.3 & 0.0 & 0.0 & 0.0 & 0.0 \\
$1-2$ & 131.6 & 23.1 & 29.4 & 8.2 & 0.0 \\
$2-3$ & 408.1 & 687.6 & 690.3 & 72.2 & 15.5 \\
$3-4$ & 307.6 & 187.9 & 72.6 & 95.5 & 133.1 \\
$4-5$ & 76.8 & 236.6 & 88.1 & 641.7 & 381.9 \\
$5-6$ & 110.9 & 644.3 & 104.5 & 97.5 & 491.4 \\
$6-7$ & 745.7 & 20.5 & 293.9 & 81.8 & 709.8 \\
$7-8$ & 0.0 & 0.0 & 521.2 & 387.3 & 68.3 \\
$8-9$ & 0.0 & 0.0 & 0.0 & 415.8 & 0.0 \\
Mean value & 4.5 & 4.0 & 4.9 & 6.1 & 5.6 \\
\hline
\end{tabular}

While examining the results, it was possible to note how the best solution is configuration 2. In this configuration, the hypothetical intervention is restricted to the basic surface of the yard where it is assumed the presence of lawn and vegetation. The mean PMV is 4.0 and there are no sections of the surface belonging to categories 7-8 and 8-9; a wide part of the surface belongs to categories $2-3\left(687.6 \mathrm{~m}^{2}\right)$.

Even in configuration 1 (the present one, which presents painted lime plaster on the facades and cobblestones on the Cloister yard), there are no sections in the Cloister belonging to category 7-8 and 8-9; what happens though is that a considerable part $\left(745.7 \mathrm{~m}^{2}\right)$ belongs to category $6-7$ and, in this way, the PMV value becomes 4.5.

Configuration 4 is then the worst: it is characterized by an increase of the albedo coefficient on both the facades and the yard floor. This determines a mean PMV of 6.1 due to a high contribution of categories 7-8 and 8-9 respectively of $387.3 \mathrm{~m}^{2}$ and $415.8 \mathrm{~m}^{2}$.

The same situation is reported in configuration 5 with the exertion of high albedo materials on the walls causing a deterioration of the outdoor thermal comfort, only in part mitigated by the lawn. The mean PMV is of 5.6 and this value is affected by the $709.8 \mathrm{~m}^{2}$ (category 6-7) and $491.4 \mathrm{~m}^{2}$ (category 5-6).

The exertion of a high albedo material just for the yard determines a less significant deterioration: in fact configuration 3 presents a mean PMV of 4.9. In this case it is possible to note the $690.3 \mathrm{~m}^{2}$ of category $2-3$ and $521.2 \mathrm{~m}^{2}$ of category $7-8$.

Examining the results reported in Table 7 and observing Figure 4, it is possible to see how there is an improvement of the thermohygrometric conditions thanks to the presence of some vegetation while the exertion of high albedo materials (in urban contexts particularly enclosed as the one studied) determines a deterioration of the microclimate.

This is due to the ability of the plants to screen solar radiation (the trees characterizing configurations 2 and 5 during the summer present a coefficient of transmissivity of $2 \%-5 \%$ ) and to have the leaf surface temperature really close to the one of the air, that is $20-35{ }^{\circ} \mathrm{C}$ lower than the surface temperature of several urban materials commonly used (asphalt, concrete, etc.). Then, it should be considered that the temperature measured through the globe thermometer under a big tree is $15-20{ }^{\circ} \mathrm{C}$ lower than the temperature measured through the globe thermometer in the same place under direct solar radiation [76,77]. A further improvement of the microclimate in configuration 2 is determined by the presence of shrubs (preventing the reflected radiation from reaching people) and a lawn (presenting a 
low level reflection and a high thermal capacity provoking cooling and humidification processes thanks to evapotranspiration phenomena, hence a decrease in air temperature).

On the other hand, configurations with a higher albedo coefficient lead to a deterioration of the outdoor thermal comfort due to an increase in the reflected radiation which in turn determines a sensible heat storage in the lower layers. This is determined by the multiple reflections being established, because of the low sky view factor of the surfaces characterized by a higher albedo, between the limits of the site examined, leading to an increase in the mean radiant temperature. From this point of view and with reference to the actual configuration of the site (configuration 1), it should be kept in mind that the exertion of a high albedo material on the basic surface of the yard (configuration 3 ) determines a reduction of the air temperature of about $0.3{ }^{\circ} \mathrm{C}$ but at the same time an increase of the mean radiant temperature of about $7{ }^{\circ} \mathrm{C}$ [78]. Differently, those configurations characterized by a higher albedo coefficient of the facades show an increase of air temperature and mean radiant temperature, for instance in configuration 4 equal to $1.5^{\circ} \mathrm{C}$ and about $20^{\circ} \mathrm{C}$, respectively [78].

For what concerns the fountain, from the analysis of Figure 4 it is possible to notice how it determines a very localized improvement of the outdoor thermal comfort. This improvement, for those standing in the surrounding area, is due to the reduction of the Bowen ratio (defined as the ratio between the sensible and latent heat flux) and to a decrease in the mean radiant temperature.

Finally, it is interesting to analyze the influence of the wind: Figure 4 reports a decrease of the PMV value right in the area of the portico placed between the two entrances where this variable reaches the highest values and the convective heat transfer increases.

\section{Conclusions}

This paper compared, through simulations performed thanks to the ENVI-met software, different microclimatic mitigation strategies in an urban context to evaluate their effect on the outdoor thermal comfort in a particular enclosed structural configuration. The case study was carried out in the Cloister of San Pietro in Vincoli with an area of $1,800 \mathrm{~m}^{2}$, situated inside the Faculty of Engineering of the Sapienza University of Rome, during a typical summer day. For what concerns the PMV, the present configuration of the site was compared to another four configurations characterized by different solutions for both the vertical and horizontal limits of the structure. Particular attention was given to the influence of the vegetation and to the use of high albedo materials.

The use of this kind of materials in particular enclosed urban contexts causes a microclimatic deterioration, hence higher thermal stresses. This increase is inversely proportional to the sky view factor of the surfaces with a high albedo.

In the case study, a higher albedo on the yard surface determines an increase of the mean PMV of about 0.4 units in respect to the present configuration; whereas if the facades are also made of a high albedo material, the mean PMV is 1.6 units higher.

The microclimatic deterioration, caused by a higher albedo on the facades, can be in part mitigated by the presence of lawn and vegetation: the evapotranspiration phenomena and the capacity of the plants to diminish the incident and reflected direct shortwave radiation reduces the increase of the mean PMV to about a single unit. 
Finally, the presence of lawn, trees and shrubs leads to an improvement of the outdoor thermal comfort if the facades do not change: in this case, the magnitude of the multiple reflections inside the structure decreases and the reduction of the mean PMV is about 0.5 units.

\section{Acknowledgments}

This research received no specific grant from any funding agency in the public, commercial, or not-for-profit sectors. A special thanks to Flavia Franco for the help she provided in the preparation of this paper.

\section{Author Contributions}

The study was designed by Ferdinando Salata, Iacopo Golasi, Franco Gugliermetti and Andrea de Lieto Vollaro. Emanuele de Lieto Vollaro, Fabio Bisegna and Fabio Nardecchia retrieved the data from yearbooks and professional websites and reviewed the literature related to the research. The results were then analysed by Ferdinando Salata, Iacopo Golasi, Massimo Coppi and Fabio Bisegna. Model design and English corrections were undertaken by Emanuele de Lieto Vollaro and Fabio Nardecchia. Finally, Franco Gugliermetti and Andrea de Lieto Vollaro, the full professors of the research group, supervised the work related to the paper and the execution of its various phases.

\section{Conflicts of Interest}

The authors declare no conflicts of interest.

\section{Nomenclature}

\begin{tabular}{|c|c|}
\hline $\mathrm{e}$ & air humidity $[\%]$ \\
\hline $\mathrm{h}_{\mathrm{C}}$ & vertical spacing of the cell $[\mathrm{m}]$; \\
\hline $\mathrm{j}$ & factor representing the $\mathrm{j}$-th cell $[\mathrm{ad}]$; \\
\hline $\mathrm{K}$ & parameter set to $0.286[\mathrm{ad}]$ \\
\hline $\mathrm{LAD}(\mathrm{z})$ & Leaf Area Density $\left[\mathrm{m}^{2} / \mathrm{m}^{3}\right]$ \\
\hline $\mathrm{LADm}$ & maximum value of the Leaf Area Density $\left[\mathrm{m}^{2} / \mathrm{m}^{3}\right]$ \\
\hline M & metabolic rate $\left[\mathrm{W} / \mathrm{m}^{2}\right]$ \\
\hline $\mathrm{n}$ & parameter set to 6 for $\mathrm{z}$ values included between 0 and $\mathrm{zm}$ and to 0.5 for $\mathrm{z}$ values \\
\hline & included between $\mathrm{Zm}$ and $\mathrm{zP}$ [ad]; \\
\hline $\mathrm{p}_{1}$ & pressure whose value is used to determine $\mathrm{T}_{\mathrm{A}}[\mathrm{hPa}]$; \\
\hline PSDRY & precipitation of the driest month during the summer $[\mathrm{mm}]$; \\
\hline PSWET $_{\text {SWT }}$ & precipitation of the wettest month during the summer $[\mathrm{mm}]$; \\
\hline PWDRY & precipitation of the driest month during winter $[\mathrm{mm}]$; \\
\hline Pwwet & precipitation of the wettest month during winter $[\mathrm{mm}]$; \\
\hline PMV & Predicted Mean Vote [ad]; \\
\hline Q & radiation budget $\left[\mathrm{W} / \mathrm{m}^{2}\right]$; \\
\hline $\mathrm{QH}_{\mathrm{H}}$ & turbulent heat flux of sensible heat $\left[\mathrm{W} / \mathrm{m}^{2}\right]$; \\
\hline$Q_{L}$ & latent heat flux $\left[\mathrm{W} / \mathrm{m}^{2}\right]$ \\
\hline
\end{tabular}




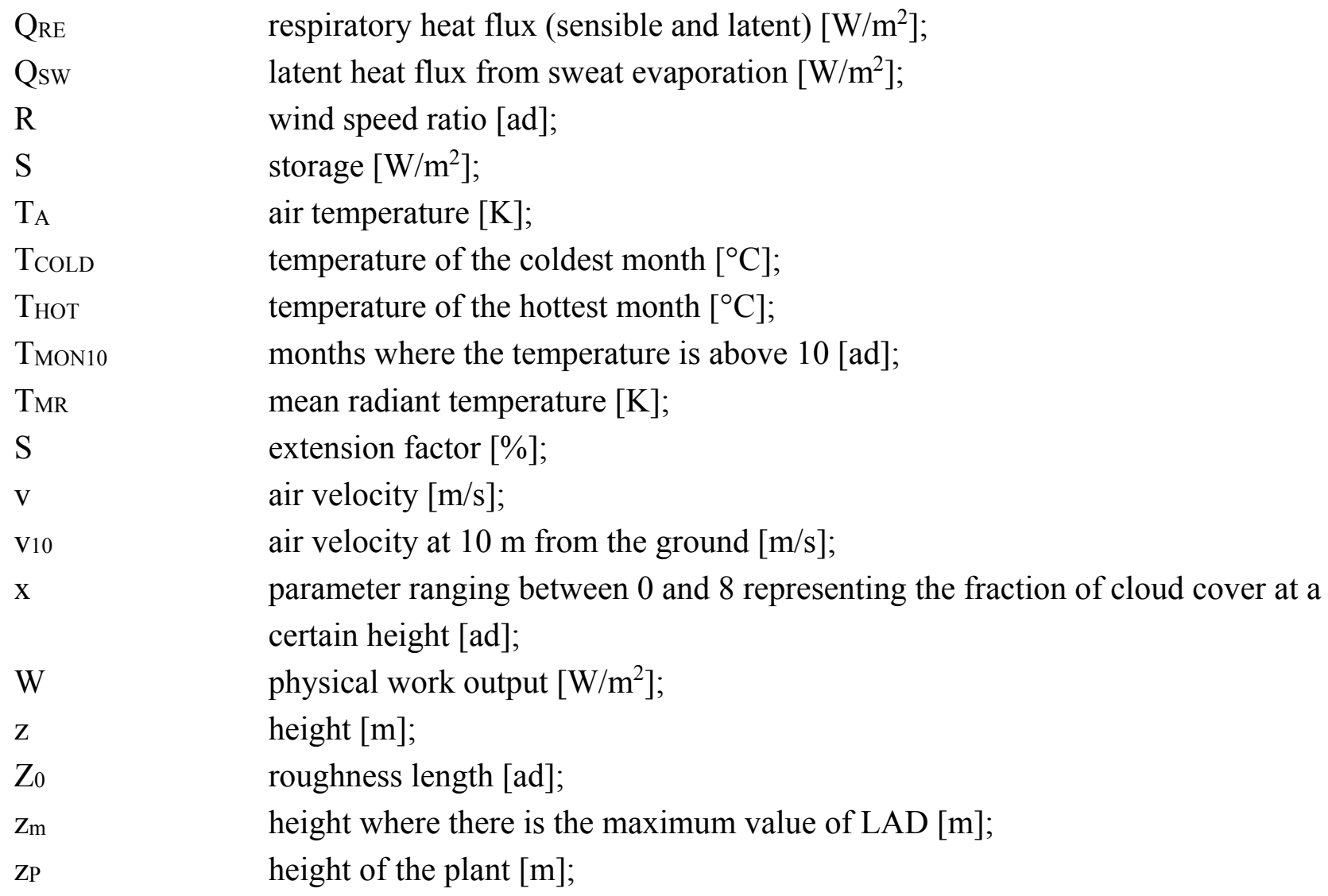

\section{Greek letters}

$\alpha F$

$\alpha \mathrm{s}$

$\varepsilon s$

$\eta$

$\theta$

short-wave albedo of the plant leaf [ad];

short-wave albedo of the considered surface [ad];

emissivity of the considered surface [ad];

mechanical factor $[\mathrm{ad}]$;

potential temperature $[\mathrm{K}]$;

\section{References}

1. Howard, L. The Climate of London; Harvey and Dorton: London, UK, 1883; Volume I-III.

2. Klyzik, K.; Fortuniak, K. Temporal and spatial characteristics of the urban heat island of Lódz, Poland. Atmos. Environ. 1999, 33, 3885-3895.

3. Livada, I.; Santamouris, M.; Niachou, K.; Papanikolaou, M.; Michalakakou, G. Determination of places in the great Athens area where the heat island effect is observed. Theor. Appl. Cimatol. 2002, 71, 219-230.

4. Miao, S.; Chen, F.; le Mone, A.M.; Tewari, M.; Li, Q.; Wang, Y. An observational and modelling study of characteristics of urban heat island and boundary layer structures in Beijing. J. Appl. Meteorol. Clim. 2009, 48, 484-501.

5. Pinho, O.S.; Manso Orgaz, M.D. The urban heat island in a small city in coastal Portugal. Int. J. Biometeorol. 2002, 44, 198-203.

6. Oke, T.R. The Energetic Basis of the Urban Heat Island. Q. J. Roy. Meteor. Soc. 1982, 108, 1-24. 
7. Arnfield, A.J. Two decades of urban climate research: A review of turbulence, exchanges of energy and water, and the urban heat island. Int. J. Climatol. 2003, 23, 1-26.

8. Christen, A.; Vogt, R. Energy and radiation balance of a central European city. Int. J. Climatol. 2004, 24, 1395-1421.

9. Grimmond, C.S.B.; Oke, T.R. Comparison of heat fluxes from summertime observations in the suburbs of four North American cities. J. Appl. Meteorol. 1995, 34, 873-889.

10. Grimmond, C.S.B.; Oke, T.R. Aerodynamic properties of urban areas derived from analysis of surface form. J. Appl. Meteorol. 1999, 38, 1262-1292.

11. Asdrubali, F.; D’Alessandro, F.; Baldinelli, G.; Bianchi, F. Evaluating in situ thermal transmittance of green buildings masonries - A case study. Case Stud. Constr. Mater. 2014, 1, 53-59.

12. Asdrubali, F.; Buratti, C.; Cotana, F.; Baldinelli, G.; Goretti, M.; Moretti, E.; Baldassarri, C.; Belloni, E.; Bianchi, F.; Rotili, A.; et al. Evaluation of Green Buildings' Overall Performance through in Situ Monitoring and Simulations. Energies 2013, 6, 6525-6547.

13. Bonamente, E.; Rossi, F.; Coccia, V.; Pisello, A.L.; Nicolini, A.; Castellani, B.; Cotana, F.; Filipponi, M.; Morini, E.; Santamouris, M. An energy-balanced analytic model for urban heat canyons: Comparison with experimental data. Adv. Build. Energy Res. 2013, 7, 222-234.

14. Kim, Y.; Baik, J. Maximum urban heat island intensity in Seoul. J. Appl. Meteorol. 2002, 41, 651-659.

15. Memon, R.A.; Leung, D.Y.C.; Liu, C.-H. An investigation of urban heat island intensity (UHII) as an indicator of urban heating. Atmos. Res. 2009, 94, 491-500.

16. Gaitani, N.; Mihalakakou, G.; Santamouris, M. On the use of bioclimatic architecture principles in order to improve thermal comfort conditions in outdoor spaces. Build Environ. 2007, 42, 317-324.

17. Oke, T.R. Initial Guidance to Obtain Representative Meteorological Observations at Urban Sites. Instruments and Methods of Observation Program; IOM Report No. 81, WMO/TD 1250; World Meteorological Organization: Geneva, Switzerland, 2004.

18. Battista, G.; Evangelisti, L.; Guattari, C.; Basilicata, C.; de Lieto Vollaro, R. Buildings Energy Efficiency: Interventions Analysis under a Smart Cities Approach. Sustainability 2014, 6, 4694-4705.

19. Pisello, A.L.; Asdrubali, F. Human-based energy retrofits in residential buildings: A cost-effective alternative to traditional physical strategies. Appl. Energy 2014, 133, 224-235.

20. Bianchi, F.; Pisello, A.L.; Baldinelli, G.; Asdrubali, F. Infrared thermography assessment of thermal bridges in building envelope: Experimental validation in a test room setup. Sustainability 2014, 6, 7107-7120.

21. Coppi, M.; Quintino, A.; Salata, F. Numerical study of a vertical channel heated from below to enhance natural ventilation in a residential building. Int. J. Vent. 2013, 12, 41-49.

22. Coppi, M.; Quintino, A.; Salata, F. Fluid dynamic feasibility study of solar chimney in residential buildings. Int. J. Heat Technol. 2011, 29, 1-5.

23. D’Orazio, A.; Fontana, L.; Salata, F. Experimental study of a semi-passive ventilation grille with a feedback control system. Rev. Sci. Instrum. 2011, 82, doi:10.1063/1.3626793.

24. Spagnolo, J.; de Dear, R. A field study of thermal comfort and semioutdoor environments in subtropical Sydney Australia. Build. Environ. 2003, 38, 721-738.

25. Givoni, B.; Noguchi, M.; Saaroni, H.; Pochter, O.; Yaacov, Y.; Feller, N.; Becker, S. Outdoor comfort research issues. Energy Build. 2003, 35, 77-86. 
26. Akbari, H.; Pomerantz, M.; Taha, H. Cool surfaces and shade threes to reduce energy use and improve air quality in urban areas. Sol. Energy 2001, 70, 295-310.

27. Rosenfeld, A.; Akbari, H.; Romm, J.J.; Pomerantz, M. Cool communities: Strategies for heat island mitigation and smog reduction. Energy Build. 1998, 28, 51-62.

28. Pisello, A.L.; Rossi, F.; Cotana, F. Summer and winter effect of innovative cool roof tiles on the dynamic thermal behavior of buildings. Energies 2014, 7, 2343-2361.

29. Rosso, F.; Pisello, A.L.; Ferrante, M.; Cotana, F. Integrated Thermal Energy Analysis of Innovative Translucent White Marble for Building Envelope Application. Sustainability 2014, 6, 5439-5462.

30. Baldinelli, G.; Bonafoni, S.; Anniballe, R.; Presciutti, A.; Gioli, B.; Magliulo, V. Spaceborne detection of roof and impervius surface albedo: Potentilities and comparison with airborne thermography measuraments. Sol. Energy 2015, 113, 281-294.

31. He, J.; Hoyano, A. Experimental study of cooling effects of a passive evaporative cooling wall constructed of porous ceramics with high water soaking-up ability. Build Environ. 2010, 45, 461-472.

32. Wanphen, S.; Nagano, K. Experimental study of the performance of porous materials to moderate the roof surface temperature by its evaporative cooling effect. Build. Environ. 2009, 44, 338-351.

33. Krüger, E.L.; Pearlmutter, D. The effect of urban evaporation on building energy demand in an arid environment. Energy Build 2008, 40, 2090-2098.

34. Runsheng, T.; Etzion, Y.; Erell, E. Experimental studies on a novel roof pond configuration for the cooling of buildings. Renew Energy 2003, 28, 1513-1522.

35. Alexandri, E.; Jones, P. Temperature decreases in an urban canyon due to green walls and green roofs in diverse climates. Build. Environ. 2008, 43, 480-493.

36. Lui, K.K.Y. Energy efficiency and environmental benefits of rooftop gardens. Constr. Can. 2002, $44,20-23$.

37. Pisello, A.L.; Piselli, C.; Cotana, F. Influence of Human Behavior on Cool Roof Effect for Summer Cooling. Build. Environ. 2015, 88, 116-128.

38. Pisello, A.L.; Pignatta, G.; Castaldo, V.L.; Cotana, F. Experimental analysis of natural gravel covering as cool roofing and cool pavement. Sustainability 2014, 6, 4706-4722.

39. Pisello, A.L.; Santamouris, M.; Cotana, F. Active cool roof effect: Impact of cool roofs on cooling system efficiency. Adv. Build. Energy Res. 2013, 7, 209-221.

40. Ascione, F.; Bianco, N.; de’ Rossi, F.; Turni, G.; Vanoli, G.P. Green roofs in European climates. Are effective solutions for the energy savings in air-conditioning? Appl. Energy 2013, 104, 845-859.

41. Akbari, H. Shade trees reduce building energy use and $\mathrm{CO}_{2}$ emissions from power plants. Environ. Pollut. 2002, 116, S119-S126.

42. Fanger, P.O. Thermal Comfort; McGraw-Hill: New York, NY, USA, 1972.

43. Jendritzky, G.; Nübler, W. A model analysing the urban thermal environment in physiologically significant terms. Meteorol. Atmos. Phys. 1981, 29, 313-326.

44. Petrarca, S.; Spinelli, F.; Cogliani, E.; Mancini, M. Profilo Climatico Dell'Italia; Edizioni ENEA: Montalcino, Italy, 1999.

45. U. S. Department of Energy, Energy Efficiency and Renewable Energy. Available online: http://apps1.eere.energy.gov/buildings/energyplus/cfm/weather_data3.cfm/region=6_europe_wmo _region_6/country=ITA/cname=Italy (accessed on 15 December 2014). 
46. Gugliermetti, F.; Passerini, G.; Bisegna, F. Climate Models for the Assessment of Office Building Energy Performance. Build. Environ. 2004, 39, 39-50.

47. Gugliermetti, F.; Bisegna, F. Meteorological Days for HVAC System Design in Mediterranean Climate. Build. Environ. 2003, 38, 1063-1074.

48. Köppen, W. Das Geographische System der Climate; Köppen, W., Geiger, R., Eds.; Handbuch der Klimatologie: Berlin, Germany, 1936.

49. Lalic, B.; Mihailovic, D.T. An Empirical relation describing Leaf Area Density inside the forest for environmental modeling. J. Appl. Meteorol. 2004, 43, 641-645.

50. Pisello, A.L.; Cotana, F.; Nicolini, A.; Brinchi, L. Development of clay tile coatings for steep-sloped cool roofs. Energies 2013, 6, 3637-3653.

51. ENVI-Met. 3.1 Manual Contents. Available online: http://www.envi-met.com/ (accessed on 18 February 2015).

52. Bruse, M.; Fleer, H. Simulating surface-plant-air interactions inside urban environments with a three dimensional numerical model. Environ. Model. Softw. 1998, 13, 373-384.

53. Wania, A.; Bruse, M.; Blond, N.; Weber, C. Analysing the influence of different street vegetation on traffic-induced particle dispersion using microscale simulations. J. Environ. Manag. 2012, 94, 91-101.

54. Samaali, M.; Courault, D.; Bruse, M.; Olioso, A.; Occelli, R. Analysis of a 3D boundary layer model at local scale: Validation on soybean surface radiative measurements. Atmos. Res. 2007, 85, 183-198.

55. ASHRAE. Thermal comfort. In ASHRAE Handbook; ASHRAE: Atlanta, GA, USA, 2009; ch. 9.

56. Beuth. Environmental Meteorology-Methods for the Human Biometeorological Evaluation of Climate and Air Quality for Urban and Regional Planning at Regional Level; Part I: Climate; Beuth Verlag: Berlin, Germany, 2008.

57. ISO 7730. Ergonomics of the Thermal Environment-Analytical Determination and Interpretation of Thermal Comfort using Calculation of the PMV and PPD Indices and Local Thermal Comfort Criteria; International Organization for Standardization: Geneva, Switzerland, 2005.

58. ASHRAE. Thermal Environmental Conditions for Human Occupancy; ASHRAE: Atlanta, GA, USA, 2010.

59. Johansson, E.; Thorsson, S.; Emmanuel, R.; Krüger, E. Instruments and methods in outdoor thermal comfort studies - The need for standardization. Urban Clim. 2014, 10, 346-366.

60. Becker, S.; Potchter, O.; Yaacov, Y. Calculated and observed human thermal sensation in an extremely hot and dry climate. Energy Build. 2003, 35, 747-756.

61. Bouden, C.; Ghrab, N. An adaptive thermal comfort model for the Tunisian context: A field study results. Energy Build. 2005, 37, 952-963.

62. Cheng, V.; Ng, E.; Chan, C.; Givoni, B. Outdoor thermal comfort study in a sub-tropical climate: A longitudinal study based in Hong Kong. Int. J. Biometeorol. 2012, 56, $43-56$.

63. Thorsson, S.; Lindqvist, M.; Lindqvist, S. Thermal bioclimatic conditions and patterns of behavior in an urban park in Göteborg, Sweden. Int. J. Biometeorol. 2004, 48, 149-156.

64. Mahmoud, A.H.A. Analysis of the microclimatic and human comfort conditions in an urban park in hot and arid regions. Build. Environ. 2011, 46, 2641-2656. 
65. Höppe, $\mathrm{P}$. The physiological equivalent temperature-A universal index for the biometeorological assessment of the thermal environment. Int. J. Biometeorol. 1999, 43, 71-75.

66. Oertel, A.; Emmanuel, R.; Drach, P. Assessment of predicted versus measured thermal comfort and optimal comfort ranges in the outdoor environment in the temperate climate of Glasgow, UK. Build. Serv. Eng. Res. Technol. 2015, 36, 482-499.

67. Nikolopoulou, M. Designing Open Spaces in the Urban Environment: A Bioclimatic Approach, Rediscovering the Urban Realm and Open Spaces. In Key Action 4 "City of Tomorrow and Cultural Heritage”; Centre for Renewable Energy Sources, Department of Buildings: Pikermi Attiki, Greece, 2004.

68. Evangelisti, L.; Battista, G.; Guattari, C.; Basilicata, C.; de Lieto Vollaro, R. Analysis of Two Models for Evaluating Energy Performance of Different Buildings. Sustainability 2014, 6, 5311-5321.

69. Evangelisti, L.; Battista, G.; Guattari, C.; Basilicata, C.; de Lieto Vollaro, R. Influence of the Thermal Inertia in the European Simplified Procedures for the Assessment of Buildings. Sustainability 2014, 6, 4514-4524.

70. De Lieto Vollaro, R.; Evangelisti, L.; Carnielo, E.; Battista, G.; Gori, P.; Guattari, C.; Fanchiotti, A. An integrated approach for an historical buildings energy analysis in a smart cities perspective. Energy Procedia 2014, 45, 372-378.

71. De Lieto Vollaro, R.; Guattari, C.; Evangelisti, L.; Battista, G.; Carnielo, E.; Gori, P. Building energy performance analisys: A case study. Energy Build. 2015, 87, 87-94.

72. De Lieto Vollaro, R.; Calvesi, M.; Battista, G.; Evangelisti, L.; Botta, F. Calculation model for optimization design of the low impact energy systems for buildings. Energy Procedia 2014, 48, 1459-1467.

73. ASHRAE. HVAC Applications. In ASHRAE Handbook; ASHRAE: Atlanta, GA, USA, 2011.

74. Profile soil temperature. Journal of Engineering Geology and Hydrogeology. Available online: http://qjegh.lyellcollection.org/content/42/3/295/F2.expansion.html (accessed on 18 February 2015).

75. ISO 7726. Ergonomics of the Thermal Environment-Instruments for Measuring Physical Quantities; International Organization for Standardization: Geneva, Switzerland, 1998.

76. Bottillo, S.; de Lieto Vollaro, A.; Galli, G.; Vallati, A. CFD modeling of the impact of solar radiation in a tridimensional urban canyon at different wind conditions. Sol. Energy 2014, 102, 212-222.

77. Bottillo, S.; de Lieto Vollaro, A.; Galli, G.; Vallati, A. Fluid dynamic and heat transfer parameters in an urban canyon. Sol. Energy 2014, 99, 1-10.

78. Salata, F.; Golasi, I.; de Lieto Vollaro, A.; de Lieto Vollaro, R. How high albedo and traditional buildings' materials and vegetation affect the quality of urban microclimate. A case study. Energy Build. 2015, 99, 32-49.

(C) 2015 by the authors; licensee MDPI, Basel, Switzerland. This article is an open access article distributed under the terms and conditions of the Creative Commons Attribution license (http://creativecommons.org/licenses/by/4.0/). 